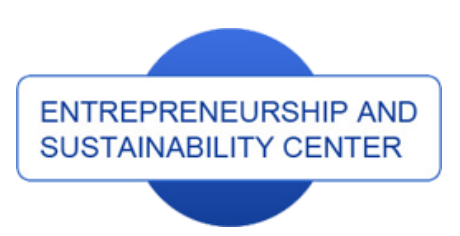

Publisher

http://jssidoi.org/esc/home

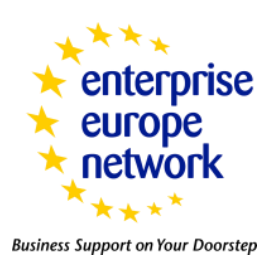

CASPA

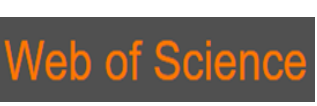

1) Clarivate

\title{
THE EFFECT OF AUDIT QUALITY AND DEGREE OF INTERNATIONAL FINANCIAL REPORTING STANDARDS (IFRS) CONVERGENCE ON THE ACCRUAL EARNINGS MANAGEMENT IN ASEAN COUNTRIES
}

\author{
Zahratun Nadhir ${ }^{1}$, Ratna Wardhani ${ }^{2}$ \\ ${ }^{1,2}$ Accounting Department, Faculty of Economics and Business, Universitas Indonesia, Depok, 16424, Indonesia \\ E-mails: ${ }^{1}$ zahratun.nadhir@ui.ac.id; ${ }^{2}$ ratna.wardhani@ui.ac.id
}

Received 10 February 2019; accepted 15 June 2019; published 30 September 2019

\begin{abstract}
The purpose of this research is to analyze the effect of the degree of convergence of International Financial Reporting Standards (IFRS) and Audit Quality on company's accrual earnings management. In addition, this research also aims to investigate the moderation role of the degree of convergence of IFRS on the relationship between audit quality and company's accrual earnings management. This research covers several Association of Southeast Asian Nations (ASEAN) countries, consists of Philippines, Indonesia, Malaysia, Singapore, Thailand, and Vietnam. The methodology used in this research is the multiple regressions by using Least Square method. This study finds that the higher the degree of convergence of IFRS, the lower discretionary accruals, which means the higher quality of earnings. Meanwhile, the size and specialization of the auditor are not significantly effecting accrual earnings management which is described by the value of discretionary accruals. The results imply that being audited by Big-4 or specialized accounting firm, does not guarantee the lower discretionary accruals, which means do not guarantee that the accrual earnings management will be better. On the other hand, the degree of convergence of IFRS did not have a moderating role that influence the effect of audit quality on the accrual earnings management.
\end{abstract}

Keywords: accrual earnings management; audit quality; ASEAN; convergence; International Financial Reporting Standards (IFRS)

Reference to this paper should be made as follows: Nadhir, Z.; Ratna Wardhani, R. 2019. The effect of audit quality and degree of international Financial Reporting Standards (IFRS) convergence on the accrual earnings management in ASEAN countries, Entrepreneurship and Sustainability Issues 7(1): 105-120. http://doi.org/10.9770/jesi.2019.7.1(9)

JEL Classifications: M40, M41, Z23

\section{Introduction}

Financial reports are required by various parties, such as investors and creditors for decision making. One of the first factors considered for decision-making is the company's ability to generate earnings. Companies with earnings that tend to remain stable and increasing are considered a company with good performance so that it is considered attractive to investors who will invest their capital or for the management to do business development. Given the importance of the income statement in the performance appraisal, the quality of the earnings reported in 


\section{ENTREPRENEURSHIP AND SUSTAINABILITY ISSUES}

ISSN 2345-0282 (online) http://jssidoi.org/jesi/ 2019 Volume 7 Number 1 (September) http://doi.org/10.9770/jesi.2019.7.1(9)

the income statement of the firm is always a concern. Dichev et al. (2016) states that earnings are said to be in high quality when earnings meet certain characteristics such as consistent, sustainable and predictable, reflects cash flow, has no one-time or special item, neutral, presented in a timely manner, clearly presented, and putting forward the principle of conservatism. On the other hand, to meet investor expectations and optimized benefits received, management has a tendency to perform treatment on earnings known as earnings management so that earnings submitted to company owners appear relatively stable (Gerayli, et al., 2011; Narkuniené, Ulbinaité, 2018; Zemguliene, Valukonis, 2018).

One of the most widely adopted accounting standards is the International Financial Reporting Standards (IFRS). IFRS requires full disclosure of each component of the financial statements. With this standard, the information disclosed by the company will be more complete, so users of financial statements can assess the company's performance with comprehensive and accurate. In addition, a standard used by all parties can improve comparability so that users of financial statements can make decisions more precisely. Thus, the adoption of IFRS is expected to improve the quality of financial statements, and the quality of earnings in particular. Prior studies, as stated by Anggraeni and Wardhani (2017), state that the use of international accounting standards has a mixed impact on various financial aspects of firms such as price reaction (Beatty, Chamberlain, \& Magliolo, 1996), cost of capital (Karamanou \& Nishiotis, 2009), information asymmetry (Cuijpers \& Buijink, 2005) and accounting quality (Ashbaugh \& Pincus, 2001; Barth et al., 2008).

To ensure that financial statements are presented in accordance with applicable accounting standards, independent external verification is required. Therefore, companies need the services of independent external auditors. An auditor provides audit services to the client's financial statements to provide assurance to the users of financial statements that the financial statements have been prepared in accordance with applicable accounting standards so that the financial statements are reliable in decision making. Auditing services also serve as a monitoring tool for potential conflicts of interest between owners and managers and shareholders with different amounts of ownership, and can reduce asymmetrical information between managers and corporate stakeholders by allowing outsiders to check the validity of financial statements (Jensen and Meckling, 1976).

As the information becomes more complete, users of financial statements will be increasingly critical in demanding the quality of earnings reported in the financial statements. These circumstances create pressure for auditors to improve the quality of audits conducted so as to ensure that reported earnings and financial statements produced are of high quality (Barth et al., 2008). Thus, it appears that IFRS convergence conducted by each country not only affects the quality of earnings directly, but also has an influence on the relationship between audit quality and earnings quality.

Previous studies have done a lot of research on the effect of IFRS convergence with earnings quality, for example Daske and Gunther (2006) state that IFRS convergence improves the quality of financial statements and Barth et al. (2008) examining accounting quality before and after the introduction of IFRS by using a sample of 327 companies in 21 countries that have voluntarily adopted IAS between 1994 and 2003. On the other hand, many studies have examined the effect of audit quality on earnings quality, eg research Gerayli et al. (2011). However, no research has been found to examine the effect of moderation of IFRS convergence on the relationship between audit quality and earnings quality. This research will try to fill the gap and complete the results from previous studies. This study aims to examine the effect of IFRS convergence and audit quality on the earnings quality measured by accrual earnings management. This study also aims to examine whether the IFRS convergence can strengthen the effect of audit quality on earnings management.

This study contributes the literature in several ways. First, this study examines the impact of IFRS and audit quality on earnings management in the context of countries in ASEAN that have high variations in the financial reporting environment. Previous research examined this in the context of developed countries or regions that have more homogeneous reporting environment characteristics. Second, in contrast to previous studies which mostly examined the impact of IFRS on the quality of financial reports by using a dummy variable by classifying a 


\section{ENTREPRENEURSHIP AND SUSTAINABILITY ISSUES}

ISSN 2345-0282 (online) http://jssidoi.org/jesi/ 2019 Volume 7 Number 1 (September) http://doi.org/10.9770/jesi.2019.7.1(9)

country adopting or not adopting IFRS, this study measures IFRS convergence by scoring against the prevailing standards in a country by using adoption levels scores. Third, this study examines the moderating effect of IFRS on the relationship between audit quality and earnings management which based on our knowledge has not been examined by previous research.

This study will take samples from six ASEAN countries: Philippines, Indonesia, Malaysia, Singapore, Thailand and Vietnam. The ASEAN region is chosen because it is an emerging region with a growing economy, so that the characteristics of the existing companies in ASEAN may be different from the companies in Europe or America that have been studied in previous research. In addition, IFRS convergence in the ASEAN region is conducted with different approaches in accordance with the policies of each country so that the degree of convergence of IFRS in ASEAN countries becomes diverse. It is an interesting phenomenon to be studied.

\section{Theory, Literatures Review and Hypothesis Development}

\subsection{Agency Theory}

Jensen \& Meckling (1976) define agency relations as contracts where one or more people acting as principals (ie shareholders / shareholders) appoint other people as agents (ie managers) to perform services for the interests of principals, including delegating power in decision making to agent. The agency relationship will cause conflict if the agent tries to maximize his/her personal utility and at the same time they sacrifice the intrest of the principals. Agents that have more information regarding companies are vulnerable to taking opportunistic actions which aim to increase wealth for the agent itself that can be detrimental to investors. To minimize this risk, the principal pays the cost to control and monitor the performance of the managers (agents) which is called the agency cost.

One way to minimize the risk of expropriation is to minimize the possibility of asymmetric information. High quality of financial reports are one mechanism to minimize asymmetric information. Agent's personal interest and probabilities of the information asymmetries can lead to the question about the reliability of information and the quality of earnings, which impacts on the impairment of trust of the principals to the agent. Several mechanisms that oftenly used by the company to align the interests of agents with principals. The mechanisms can be at country level such as investor protection, legal quality, and also accounting standard adopted by a country or at firm level such as remuneration package, firm level corporate governance, and also audit quality. Accounting standard adopted in a country can be a mechanism to improve the reporting environment. Moreover, audits also serve a vital economic purpose in the monitoring mechanism and also play an important role in increasing the quality of financial reporting.

\subsection{Hypothesis Development}

Referring to the research of Dichev et al. (2016), the earnings are said to be in a high quality if it meets certain characteristics such as consistent, sustainable and predictable, reflects cash flow, lacks one-time or special items, is neutral, presented in a timely manner, presented clearly, and put forward the principle of conservatism. The quality of corporate earningss is influenced by external factors and internal factors of the company, among others: (i) the convergence level of countries' standards with IFRS; and (ii) audit quality.

The accounting standards is one of the country level monitoring mechanism for the company. The applicable accounting standards in a country will determine the quality of financial information, especially with regard to earnings information, generated by companies in that country. The use of different accounting standards leads to variations in recording and reporting that allow for more variety of gaps and variations that management can perform in the framework of earnings management that will reduce earnings quality (Dichev et al., 2016). IFRS adoption as an international accounting standard guarantees high reporting quality, because it is based on international standards supported by the IASB as a competent world-class standard setter. With the adoption of 


\section{ENTREPRENEURSHIP AND SUSTAINABILITY ISSUES}

ISSN 2345-0282 (online) http://jssidoi.org/jesi/ 2019 Volume 7 Number 1 (September) http://doi.org/10.9770/jesi.2019.7.1(9)

IFRS, the variety across countries in the accounting procedure and accounting practices can be reduced so that the possibility of management manipulating records and reporting can also be reduced. Moreover, IFRS also have more disclosure requirement compare to local accounting standards in many countries (Pirzada, K., 2016).

Several studies related to the role of accounting standards on the processes and results of financial reporting (Cohen, 2003; Daske and Gunther, 2007; Enomoto et al., 2015; Halabi \& Zakaria, 2013) show that international accounting standards positively affects financial reporting quality by increasing the comparability and reliability of the financial statements. The study proves that IFRS adoption decreases the level of discretionary accruals, which has a positive effect on earnings quality. In Asian context, Wardhani et al. (2015) also show that the adoption of IFRS positively affect the financial reporting quality. This study use accrual earnings management to proxy earnings quality, the lower earnings management reflect higher earnings quality. Thus, it can be proposed the following hypothesis:

\section{Hypothesis 1: The degree of IFRS convergence to local accounting standards has a negative effect on the accrual earnings management.}

In addition to accounting standards, audit quality also plays a role in the financial reporting process is to encourage the application of accounting standards. Based on agency theory by Jensen and Meckling (1976), audit process is one of the mechanism in the monitoring process. Auditor provide independent verification services on the financial statement so that creadibility of information is increased. In order to monitor the agent, the principals require high quality set of information. An audit process can provide the principal a verification of the information disclosed by management.

DeAngelo (1981) defines audit quality as a market assessment of the likelihood that the auditor will find an offense in the client's accounting system and report the violation. He argues that audit quality increases with audit firm size because large audit firms possess higher ability to do specialization and innovation through technology. Thus, the likelihood of a large audit firm to find violations in the corporate accounting system is greater than that of a small audit firm. Given the resources and comparative advantages possessed by large auditors, the detection and correction of corporate financial reporting mistakes can be done better.

According to Gerayli et al. (2011), audit quality has several dimensions of audit firm size (Big-4 audit firm and non Big-4 audit firm), independence and specialization of auditor industry. According to Craswell et al. (1995), large audit firms provide more human resources for staff training and skills development in certain industries than small audit firms, and also have a better position to negotiate with clients. Therefore, Big-4 auditors has good audit quality (Gerayli et al., 2011). The industry specialization of the auditor was originally defined as an auditor auditing more than 10 percent of the company's revenue in one industry (Craswell et al., 1995). After the consolidation of the Big- 8 became the Big-6, the specialization measure became 15 percent as a threshold (Krishnan 2003) to 20 percent (Dunn et al. 2000). According to (Solikhah, B., Della Firmansyah, N. and Pirzada, K. 2017), the Auditor is said to be a specialist if the auditor audits $15 \%$ of the total companies in the industry, according to Craswell et al. (1995). This classification is based on the percentage of the number of companies audited by auditors in an industry (Balsam et al., 2003). Based on the explanation above, the hypotheses are as follow:

Hypothesis 2a: The earnings management of firms audited by auditors of Big-4 is lower than the earnings management of firms audited by auditors of non Big-4.

Hypothesis 2b: The earnings management of firms audited by auditor with industry specialization is lower than the the earnings management of firms audited by auditors without industry specialization.

Auditors provide audit service to the company by providing an assurance to users of financial statements and provide an opinion whether the financial statement is fairly represent in accordance with applicable accounting standards so that financial statements are reliable in decision making. With IFRS characteristics requiring full disclosure, auditors are also required to improve the quality of their audits to ensure the quality of financial 


\section{ENTREPRENEURSHIP AND SUSTAINABILITY ISSUES}

ISSN 2345-0282 (online) http://jssidoi.org/jesi/ 2019 Volume 7 Number 1 (September) http://doi.org/10.9770/jesi.2019.7.1(9)

statements. On the other hand, IFRS as a universal accounting standard causes information obtained by users of financial statements more comprehensive and comprehensive.

As the information becomes more complete, users of financial statements will be increasingly critical in demanding the quality of earnings reported in the financial statements. This situation creates pressure for auditors to improve the quality of audits conducted so as to ensure that the resulting financial statements have high quality (Barth et al., 2008). Thus, it appears that IFRS convergence conducted by each country not only affects the quality of earnings directly, but also has an influence on the relationship between audit quality and earnings quality. Thus, it can be proposed the following hypothesis:

\section{Hypothesis 3a: The level of convergence to IFRS will strengthen the negative effect of auditor's size on earnings management}

\section{Hypothesis 3b: The level of convergence to IFRS will strengthen the negative effect of auditor's industry specialization on earnings management}

\section{Research Methodology}

The data used in this research is financial report data from companies listed on the stock exchange, obtained from Thomson Reuters EIKON database with sample company selection method used in this research is purposive sampling. The company criteria sampled are listed on the stock exchanges in the ASEAN countries: Philippines, Indonesia, Malaysia, Singapore, Thailand and Vietnam, excluding the financial industry and have complete data in the period 2014-2015. In addition, data on the similarities and differences between local accounting standards of a country and IFRS issued by PricewaterhouseCoopers (2015) and Deloitte (2016) are used. Based on the sample selection procedure, 503 sample companies were obtained. We also treat outlier by delating observations that fall outside the average \pm 3 times standard deviation for each variable in all research model.

The dependent variable of this study is the discretionary accruals value which is the residual value of Jones Model with performance-matched discretionary accruals based on the research of Dechow et al. (1995). To obtain the residual value, regression is done by Least Square method for each data group made based on country and industry field which is reflected in the code of Global Industry Classification Standard (GICS) Sector Code that exist in each company. Industrial sectors with at least 20 samples of firms in a country are grouped into one separate group, while industry sectors with samples of less than 20 companies are included in the 'Others' group.

After data grouping, regression is done to find the residual value of the following Jones Model:

$\frac{A C C}{T A_{-1}}=a_{0} \frac{1}{T A_{-1}}+a_{1} \frac{P P E}{T A_{-1}}+a_{2} \frac{\Delta S A L E S}{T A_{-1}}+\varepsilon$

Where:

ACC $=$ total accrual of firm $\mathrm{i}$ in period $\mathrm{t}$

TA-1 = total initial asset of period

PPE = gross property, plant, and equipment.

$\triangle$ SALES $\quad=$ change of company's sales $\mathrm{i}$ in period $\mathrm{t}-1$ to $\mathrm{t}$.

The independent variable in this research is the level of IFRS convergence and audit quality. The model used in this research also use control variable that is firm size, financial leverage, operating cash flow ratio, growth prospect, country market capitalization, loss and dummy variable of country with Philippines as reference. In this research, four models are created which each will be regress by using least square method to describe the relationship between independent variable and dependent variable: 
Model 1a

ADACi $=$ b0 + b1IFRSi + b2BIGi + b3SIZEi + b4LEVi + b5OCFi + b6GROWi + b7LOSSi + b8MCAPi + b913 CRTYi $+\varepsilon i$

This model illustrates the relationship between the degree of IFRS convergence and audit quality measured by the auditor's size on company's on discretionary accruals.

Model 1b

ADACi $=$ b0 + b1IFRSi + b2SPECi + b3SIZEi + b4LEVi + b5OCFi + b6GROWi + b7LOSSi + b8MCAPi + b9$13 \mathrm{CRTYi}+\varepsilon \mathrm{i}$

This model illustrates the relationship between the degree of IFRS convergence and audit quality as measured by the auditor industry's specialization on company's discretionary accruals.

Model 2a

ADACi $=$ b0 + b1IFRSi + b2BIGi + b3IFRSi*BIGi + b4SIZEi + b5LEVi + b6OCFi + b7GROWi + b8LOSSi + b9MCAPi + b10-14CRTYi + $i$

This model illustrates the role of moderation effect between the degree of IFRS convergence and audit quality as measured by the auditor's size on discretionary accruals.

Model 2b

ADACi $=$ b0 + b1IFRSi + b2SPECi + b3IFRSi*SPECi + b4SIZEi + b5LEVi + b6OCFi + b7GROWi + b8LOSSi + b9MCAPi + b10-14CRTYi $+\varepsilon$

This model illustrates the role of moderation effect between the degree of IFRS convergence and audit quality as measured by the auditor's industry specialization on discretionary accruals.

The operationalization of the variables of the four models above are as follow:

ADAC $=$ Natural logarithm of absolute discretionary accruals using modified jones model

IFRS = Index of IFRS convergence degree, average score of scoring result of each aspect of IFRS against standard applicable in each country with scoring as follows:

- 1 , if no local standard is equivalent to IFRS standard.

- 2, if there are local standards equivalent to IFRS standards but not the same.

- 3, if there are local standards equivalent to IFRS standards and the same but with certain exceptions.

- 4, if there are local standards equivalent to IFRS standards and the same for all material aspects.

BIG $=$ Variable dummy auditor. 1 for companies audited by Big 4 auditors, and a value of 0 for Non-Big 4

SPEC = Dummy variables of auditor specialization. 1 if the company is audited by the auditor industry specialization, and 0 if not.

SIZE = Company size, natural logarithm of total company asset

LEV = Financial Leverage, Total Debt $/$ Total Assets

$\mathrm{OCF}=$ Operating Cash Flow Ratio, cash flow from operating activities / total assets

GROW = Growth Prospect, Market-to-book value ratio

LOSS $=$ Dummy variable, 1 for negative net profit and 0 for vice versa.

MCAP = Country Market Capitalization / GDP.

CRTY = Dummy variable, 1 for the country concerned and 0 for other value, by making the Philippines as a reference.

In each model will be tested classical assumptions that include multicollinearity test, heteroscedasticity test, autocorrelation test and data normality test. 


\section{Analysis of the Result}

\subsection{Descriptive Statistics}

Based on the data that has been obtained, this research has 503 sample of companies. Of the 503 companies there are 103 data which is the outlier so that is removed from the sample. In addition, there are two companies that are excluded from the sample because they have negative equity where the total liability value is greater than the total asset value so that the data used in the regression model is 398 data (Table 1).

Table 1. Descriptive Statistic

\begin{tabular}{|l|l|l|l|l|l|l|}
\hline Variabel & $\mathrm{N}$ & Mean & Median & Max & Min & Stdev \\
\hline ADAC & 398 & 3.3119 & 3.3594 & 4.6600 & 1.9106 & 0.5129 \\
\hline IFRS & 398 & 3.3675 & 3.6905 & 3.8571 & 2.3810 & 0.4958 \\
\hline SIZE & 398 & 20.2696 & 20.1445 & 24.8235 & 16.6766 & 1.5670 \\
\hline LEV & 398 & 0.0919 & 0.0878 & 0.2692 & 0.0055 & 0.0594 \\
\hline OCF & 398 & 0.0825 & 0.0795 & 0.3373 & -0.1561 & 0.0838 \\
\hline GROW & 398 & 0.5560 & 0.5493 & 5.2326 & -1.6088 & 0.8306 \\
\hline MCAP & 398 & 4.4836 & 4.4801 & 5.3873 & 3.2882 & 0.6009 \\
\hline \multicolumn{7}{|l|}{} \\
\hline Variabel & $\mathrm{N}$ & $\%$ of 0 & $\%$ of 1 & \\
\hline BIG & 398 & $24.59 \%$ & $75.41 \%$ & $100 \%$ \\
\hline SPEC & 398 & $20.37 \%$ & $79.63 \%$ \\
\hline LOSS & 398 & $90.73 \%$ & $9.37 \%$ & $100 \%$ \\
\hline
\end{tabular}

From the above calculations, in IFRS score variables for example, it appears from the score of 1-4 used, the average convergence rate of the six countries ranges in number 3, which means that there is a local standard equivalent to the IFRS standard and the same but with the exception certain. Appear more than $75 \%$ of the sample firms are audited by Big-4 auditors and over $79 \%$ of companies being sampled are audited by auditors with industry specialization. From the above data, it appears that the percentage of firms audited by auditors with industry specialization is larger than firms audited by Big-4 auditors, which indicates that in the countries sampled this study, the auditor with industry specialization is not always Big-4 auditors.

\subsection{Analysis of Regression Result of Model 1a}

The regression results of Model 1a is presented in table 2 bellow. In the $t$ test analysis for each variable, the IFRS variable (Degrees of IFRS Convergence) has a significant effect on the quality of earnings described by the discretionary accruals with the direction of the negative relationship. That is, the higher the degree of convergence IFRS, the lower the possibility of discretionary accruals which means the quality of corporate earnings will be better. These results are consistent with the research of Daske and Gunther (2006), Chiu et al. (2013), Dimitropoulos et al. (2013) and Ismail et al. (2013) that examines the effect of standards on the quality of financial statements with the result that in general the universal standard (IFRS) has a positive effect on the quality of financial statements. 


\section{ENTREPRENEURSHIP AND SUSTAINABILITY ISSUES}

ISSN 2345-0282 (online) http://jssidoi.org/jesi/ 2019 Volume 7 Number 1 (September) http://doi.org/10.9770/jesi.2019.7.1(9)

Table 2. Regression Result of Model 1a

\begin{tabular}{|c|c|c|c|c|c|c|}
\hline \multicolumn{7}{|c|}{$\begin{array}{c}\text { Model 1a } \\
\mathrm{ADACi}=\mathrm{b} 0+\mathrm{b} 1 \mathrm{IFRSi}+\mathrm{b} 2 \mathrm{BIGi}+\mathrm{b} 3 \mathrm{SIZEi}+\mathrm{b} 4 \mathrm{LEVi}+\mathrm{b} 5 \mathrm{OCFi}+\mathrm{b} 6 \mathrm{GROWi}+\mathrm{b} 7 \mathrm{LOSSi}+\mathrm{b} 8 \mathrm{MCAPi}+\mathrm{b} 9-13 \mathrm{CRTY} i+\varepsilon i\end{array}$} \\
\hline \multicolumn{7}{|c|}{ Dependent Variable: ADAC } \\
\hline Independent Variable & Expected Sign & Coefficient & Std. Error & t-Statistic & \multicolumn{2}{|l|}{ Prob. } \\
\hline $\mathrm{C}$ & $?$ & -0.1411 & 0.6474 & -0.4433 & 0.4079 & \\
\hline IFRS & - & -0.3478 & 0.1280 & -5.2144 & 0.0046 & $* * *$ \\
\hline $\mathrm{BIG}$ & - & -0.0844 & 0.0835 & -2.0110 & 0.1497 & \\
\hline SIZE & $+/-$ & 0.1529 & 0.0252 & 5.9836 & 0.0000 & $* * *$ \\
\hline LEV & $+/-$ & -0.2900 & 0.0855 & -3.4080 & 0.0008 & $* * *$ \\
\hline OCF & $+/-$ & 1.4199 & 0.4458 & 3.1011 & 0.0014 & $* * *$ \\
\hline GROW & $+/-$ & -0.1104 & 0.0468 & -2.4034 & 0.0167 & $* *$ \\
\hline LOSS & $+/-$ & -0.7802 & 0.1187 & -6.5816 & 0.0000 & $* * *$ \\
\hline MCAP & $+/-$ & 0.2476 & 0.1330 & 1.8388 & 0.0618 & $*$ \\
\hline D_COUNTRY & $+1-$ & Included & & & & \\
\hline $\mathrm{N}$ & & & & 398 & & \\
\hline Adjusted R-squared & & & & 0.4008 & & \\
\hline Prob(F-statistic) & & & & 0.0000 & & \\
\hline \multicolumn{7}{|c|}{$\begin{array}{l}\text { Table Description: } \\
\text { *** Significant at level 1\%; ** Significant at the 5\% level; * Significant at level } 10 \% \\
\text { The dependent variable in this model is ADAC. The independent variables in this model are: (i) IFRS: Index of IFRS convergence degree } \\
\text { in a country; (ii) BIG: Dummy auditor variable, value } 1 \text { for companies audited by Big } 4 \text { auditor, and value } 0 \text { for Non-Big } 4 \text {. Big } 4 \text { auditors } \\
\text { are Ernst \& Young, Pricewaterhouse Cooper, Deloitte, and KPMG; (iii) SIZE: Natural logarithm of the total assets of the company; (iv) } \\
\text { LEV: Natural logarithm of total debt / total assets; (v) OCF: Natural logarithm of cash flows from operating activities / total assets; (vi) } \\
\text { GROW: Natural logarithm of market value / book value; (vii) LOSS: Dummy variable, } 1 \text { for negative net profit and } 0 \text { for vice versa; (viii) } \\
\text { MCAP: Country Market Capitalization / GDP; (ix) CRTY Dummy variables, } 1 \text { for the country concerned and } 0 \text { for other, the Philippines as } \\
\text { country of reference. }\end{array}$} \\
\hline
\end{tabular}

The results of this study prove that the adoption of IFRS as an international accounting standard in general ensures high reporting quality. Although the adoption of IFRS in sample countries varies, in general the use of international accounting standards has had a positive impact on financial reporting with increasing comparability and reliability of financial statements. Thus, Hypothesis 1: The degree of IFRS convergence to local accounting standards positively affects the quality of a company's earnings received.

The BIG variable (Auditor Size) has no significant effect on the quality of the earnings described by the discretionary accruals value with the direction of the negative relationship. From the data obtained, visible from the six sample countries, $76.25 \%$ of the sample companies were audited by Big-4 auditors. That is, from the companies being sampled, it appears that companies with good earnings quality as well as companies with poor quality earnings turn out to be mostly both audited by auditors of Big-4 auditors and associated. Thus, the level of audit quality impact in this model is measured by auditor's size to be insignificant. From the above results, it can be concluded that auditor size variables have no significant effect on the quality of earnings described by the value of discretionary accruals, so Hypothesis $2 \mathrm{a}$ is rejected.

Related to control variables, SIZE (Company Size) and OCF (Operating Cash Flow Ratio) have a significant effect on the quality of earnings described by the value of discretionary accruals with the direction of positive relationship. That is, the larger the size of the company or the ratio of cash flows from operating activities divided by total assets, the higher the possibility of discretionary accruals which means the quality of corporate earnings will decrease. Meanwhile, other control variables such as GROW (Growth Prospect) have a significant effect on the quality of earnings described by the discretionary accruals with the direction of the negative relationship.Variable LEV (Leverage) have a significant effect to the earnings quality which is described with the value of discretionary accruals with the direction of negative relationship. The LOSS (Loss) variable also has a 
significant effect on the earnings quality described by the discretionary accruals with the direction of the negative relationship. That is, in companies that experience losses, the higher the possibility of discretionary accruals which means the earnings quality will decrease. The Country Market Capitalization (MCAP) variable has no significant effect on the earnings quality described by the discretionary accruals with the direction of the positive relationship. That is, in countries with well-developed capital markets, it does not guarantee the possibility of discretionary accruals will be lower, which means that in countries with well-developed capital markets, does not guarantee the earnings quality will be higher.

\subsection{Analysis of Regression Result of Model 1b}

Model $1 \mathrm{~b}$ is a model without a moderation relationship testing Hypothesis 1 that is the degree of convergence IFRS to local accounting standards have a positive effect on the quality of a company's earnings indicated by the negative impact on discretionary accruals and Hypothesis $2 \mathrm{~b}$ is the industry specialization auditor positively affect the quality of a company's earnings which is indicated by a negative influence on discretionary accruals. From the regression results, obtained the following information (Table 3):

Table 3. Regression Result of Model 1b

\begin{tabular}{|c|c|c|c|c|c|c|}
\hline \multicolumn{7}{|c|}{ 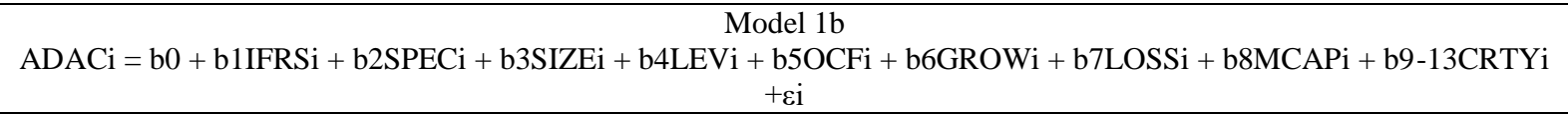 } \\
\hline \multicolumn{7}{|c|}{ Dependent Variable: ADAC } \\
\hline Independent Variable & Expected Sign & Coefficient & Std. Error & t-Statistic & \multicolumn{2}{|l|}{ Prob. } \\
\hline $\mathrm{C}$ & $?$ & -0.0605 & 0.6507 & -0.1860 & 0.4689 & \\
\hline IFRS & - & -0.3501 & 0.1288 & -5.2970 & 0.0044 & $* * *$ \\
\hline SPEC & - & -0.0011 & 0.0860 & -0.0242 & 0.4758 & \\
\hline SIZE & $+/-$ & 0.1463 & 0.0249 & 5.6643 & 0.0000 & $* * *$ \\
\hline LEV & $+/-$ & -0.2805 & 0.0860 & -3.2448 & 0.0009 & $* * *$ \\
\hline $\mathrm{OCF}$ & $+/-$ & 1.4083 & 0.4387 & 2.9780 & 0.0022 & $* * *$ \\
\hline GROW & $+/-$ & -0.1046 & 0.0466 & -2.3003 & 0.0218 & $* *$ \\
\hline LOSS & $+/-$ & -0.8048 & 0.1160 & -6.7766 & 0.0000 & $* * *$ \\
\hline MCAP & $+/-$ & 0.2486 & 0.1332 & 1.8125 & 0.0624 & $*$ \\
\hline D_COUNTRY & $+/-$ & \multicolumn{5}{|l|}{ Included } \\
\hline \multicolumn{3}{|l|}{$\mathrm{N}$} & \multicolumn{4}{|l|}{398} \\
\hline \multicolumn{3}{|l|}{ Adjusted R-squared } & \multicolumn{4}{|l|}{0.4914} \\
\hline \multicolumn{3}{|l|}{ Prob(F-statistic) } & \multicolumn{4}{|l|}{0.0000} \\
\hline \multicolumn{7}{|c|}{$\begin{array}{l}\text { Table Description: } \\
\text { *** Significant at level 1\%; ** Significant at the } 5 \% \text { level; * Significant at level } 10 \% \\
\text { The dependent variable in this model is ADAC. The independent variables in this model are as follows: (i) IFRS: Index of } \\
\text { IFRS convergence degree in a country; (ii) SPEC: Dummy auditor variable, value } 1 \text { for companies audited by auditor with } \\
\text { industry specialization, and value } 0 \text { for other; (iii) SIZE: Natural logarithm of the total assets of the company; (iv) LEV: } \\
\text { Natural logarithm of total debt / total assets; (v) OCF: Natural logarithm of cash flows from operating activities / total } \\
\text { assets; (vi) GROW: Natural logarithm of market value / book value; (vii) LOSS: Dummy variable, } 1 \text { for negative net profit } \\
\text { and } 0 \text { for vice versa; (viii) MCAP: Country Market Capitalization / GDP; (ix) CRTY Dummy variables, } 1 \text { for the country } \\
\text { concerned and } 0 \text { for other, the Philippines as country of reference }\end{array}$} \\
\hline
\end{tabular}

The SPEC (Auditor Specialization) variable has no significant effect on the earnings quality described by the discretionary accruals value despite the negative direction of the relationship. That is, there does not seem to be a link between auditor specialization and earnings quality. This is in line with the conclusions drawn by Gerayli et al. (2011) evaluating the effect of audit quality (judging by the size of audit firm and auditor industry specialization) on earnings quality and the conclusion of Enomoto et al. (2015) comparing the effect of investor protection to earnings management in 38 countries in the world and then drawing the conclusion that in general 


\section{ENTREPRENEURSHIP AND SUSTAINABILITY ISSUES}

ISSN 2345-0282 (online) http://jssidoi.org/jesi/ 2019 Volume 7 Number 1 (September) http://doi.org/10.9770/jesi.2019.7.1(9)

audit quality control (in this case indicated by auditor specialization) has no effect on earnings management. In line with the data used for model 1a, on data extracted from public companies in six ASEAN countries sampled, $79.50 \%$ of the sample companies have been audited by auditors with industry specializations. That is, most of the companies being sampled have been audited by auditors with industry specializations which show that in general most of the companies that have been sampled have good audit quality. From the sample companies, it appears that companies with good earnings quality as well as companies with poor earnings quality turn out to be mostly audited by a specialist auditor, so the level of audit quality impact in this model is measured by specialization the auditor becomes insignificant. Thus, Hypothesis $2 \mathrm{~b}$ : Auditor specialization positively affects the earnings quality of a company is rejected.

From the two models above, it appears that the effect of audit quality on earnings quality in sample countries is not significant. This is illustrated in the descriptive statistics which show that the company being sampled, whether the quality of the company's earnings is good or the quality of the company's earnings is not good, most have been audited by a qualified auditor, as measured by association with audit firm The-Big- 4 or by auditors who are considered to have specialized in one industry area in each country. Thus, the effect of audit quality on the quality of corporate earnings is not significant.

\subsection{Analysis of Regression Result of Model 2a}

Model 2a is a model with moderation relation depicting Hypothesis 3a that the level of IFRS convergence to local accounting standard will strengthen the positive influence of audit quality on earnings quality. From the regression results, obtained the following information (Table 4):

Table 4. Regression Result of Model 2a

\begin{tabular}{|c|c|c|c|c|c|c|}
\hline \multicolumn{7}{|c|}{$\begin{array}{c}\text { Model 2a } \\
\mathrm{ADACi}=\mathrm{b} 0+\mathrm{b} 1 \mathrm{IFRSi}+\mathrm{b} 2 \mathrm{BIGi}+\mathrm{b} 3 \mathrm{IFRSi} * \mathrm{BIGi}+\mathrm{b} 4 \mathrm{SIZEi}+\mathrm{b} 5 \mathrm{LEVi}+\mathrm{b} 6 \mathrm{OCFi}+\mathrm{b} 7 \mathrm{GROWi}+\mathrm{b} 8 \mathrm{LOSSi}+\mathrm{b} 9 \mathrm{MCAPi} \\
+\mathrm{b} 10-14 \mathrm{CRTY}+\varepsilon i\end{array}$} \\
\hline \multicolumn{7}{|c|}{ Dependent Variable: ADAC } \\
\hline Independen Variable & $\begin{array}{l}\text { Expected } \\
\text { Sign }\end{array}$ & Coefficient & Std. Error & t-Statistic & \multicolumn{2}{|l|}{ Prob. } \\
\hline $\mathrm{C}$ & $?$ & -0.3125 & 0.7599 & -0.4091 & 0.6667 & \\
\hline IFRS & - & -0.2828 & 0.1873 & -3.0714 & 0.0628 & $*$ \\
\hline BIG & - & -0.1590 & 0.5438 & -0.5656 & 0.3743 & \\
\hline IFRS*BIG & - & -0.0743 & 0.1570 & -0.8956 & 0.3240 & \\
\hline SIZE & $+/-$ & 0.1542 & 0.0259 & 5.9131 & 0.0000 & $* * *$ \\
\hline LEV & $+/-$ & -0.2926 & 0.0839 & -3.3885 & 0.0007 & $* * *$ \\
\hline OCF & $+/-$ & 1.4402 & 0.4561 & 3.1769 & 0.0015 & $* * *$ \\
\hline GROW & $+/-$ & -0.1102 & 0.0454 & -2.3461 & 0.0169 & $* *$ \\
\hline LOSS & $+/-$ & -0.7760 & 0.1136 & -6.5284 & 0.0000 & $* * *$ \\
\hline MCAP & $+/-$ & 0.2479 & 0.1334 & 1.7362 & 0.0697 & $*$ \\
\hline D_COUNTRY & $+/-$ & \multicolumn{5}{|l|}{ Included } \\
\hline \multicolumn{3}{|l|}{$\mathrm{N}$} & \multicolumn{4}{|l|}{398} \\
\hline \multicolumn{3}{|l|}{ Adjusted R-squared } & \multicolumn{4}{|l|}{0.4934} \\
\hline \multicolumn{3}{|l|}{ Prob(F-statistic) } & \multicolumn{4}{|l|}{0.0000} \\
\hline \multicolumn{7}{|c|}{$\begin{array}{l}\text { Table Description: } \\
\text { *** Significant at level } 1 \% \text {; ** Significant at the } 5 \% \text { level; * Significant at level } 10 \% \\
\text { The dependent variable in this model is ADAC. The independent variables in this model are : (i) IFRS: Index of IFRS } \\
\text { convergence degree in a country; (ii) SPEC: Dummy auditor variable, value } 1 \text { for companies audited by auditor with } \\
\text { industry specialization, and value } 0 \text { for other; (iii) SIZE: Natural logarithm of the total assets of the company; (iv) LEV: } \\
\text { Natural logarithm of total debt / total assets; (v) OCF: Natural logarithm of cash flows from operating activities / total } \\
\text { assets; (vi) GROW: Natural logarithm of market value / book value; (vii) LOSS: Dummy variable, } 1 \text { for negative net profit } \\
\text { and } 0 \text { for vice versa; (viii) MCAP: Country Market Capitalization / GDP; (ix) CRTY Dummy variables, } 1 \text { for the country } \\
\text { concerned and } 0 \text { for other, the Philippines as country of reference. }\end{array}$} \\
\hline
\end{tabular}


From the above regression results, the R-squared value of 0,5164 , which means the independent variable in this model is able to explain the dependent variable of approximately $51.64 \%$. Thus, the model used can be quite good because it can represent variation of dependent variable by more than $50 \%$. Independent variables have F-statistic significance with significance level less than 5\%. Thus the regression results of this model indicate that together independent variables (IFRS, BIG, SIZE, LEV, OCF, GROWTH, LOSS, MCAP and CRTY) affect the earnings quality described by the value of discretionary accruals.

In the $t$ test analysis per variable, the IFRS variable (Degrees of IFRS Convergence) has a significant effect on the earnings quality described by the discretionary accruals with the direction of the negative relationship. This result is in line with the result of the previous model. As for the BIG variable (Auditor Size) as model 1a does not significantly affect the earnings quality described by the discretionary accruals value with the direction of the negative relationship. Similarly, the BIG * IFRS variable which in this model has no significant effect and does not affect the relationship between independent variables with the dependent variable. Thus, in this model, the IFRS variable is simply a Moderator Predictor which means it only has a role as an independent predictor variable in the established relationship model. Thus, it can be concluded that hypothesis $3 \mathrm{a}$ which states the level of IFRS convergence to local accounting standards will strengthen the positive effect of auditor size on the quality of earnings is not accepted.

IFRS as a universal accounting standard causes information obtained by users of financial statements more complete and comprehensive. As the information becomes more complete, users of financial statements will be increasingly critical in demanding the quality of earnings reported in the financial statements. These circumstances create pressure for auditors to improve the quality of audits conducted so as to ensure that reported earnings and financial statements produced are of high quality (Barth et al., 2008). However, in ASEAN countries with varying levels of IFRS convergence, there appears to be an adaptation between the audit process of IFRS convergence applied to individual countries. Thus, the varying levels of IFRS convergence provide flexibility for both companies and auditors so that the implementation of IFRS does not fully appear to affect the relationship between audit quality to earnings quality. Thus, hypothesis 3a which states IFRS convergence rate to local accounting standards will reinforce the positive effect of auditor's audit firm measure on earnings quality, not accepted. 


\section{ENTREPRENEURSHIP AND SUSTAINABILITY ISSUES}

ISSN 2345-0282 (online) http://jssidoi.org/jesi/ 2019 Volume 7 Number 1 (September) http://doi.org/10.9770/jesi.2019.7.1(9)

\subsection{Analysis of Regression Result of Model 2b}

Model $2 b$ is a model with a moderation relation depicting Hypothesis $3 b$ ie that IFRS convergence level to local accounting standard strengthens the positive influence of auditor industry's specialization on earnings quality. From the regression results, obtained the following information (Table 5):

Table 5. Regression Result of Model 2b

\begin{tabular}{|c|c|c|c|c|c|c|}
\hline \multicolumn{7}{|c|}{$\begin{array}{c}\text { Model 2b } \\
\text { ADACi }=\text { b0 + b1IFRSi + b2SPECi + b3IFRSi*SPECi + b4SIZEi + b5LEVi + b6OCFi + b7GROWi + b8LOSSi + } \\
\text { b9MCAPi + b10-14CRTYi + } i ~\end{array}$} \\
\hline \multicolumn{7}{|c|}{ Dependent Variable: ADAC } \\
\hline Independent Variable & Expected Sign & Coefficient & Std. Error & t-Statistic & \multicolumn{2}{|l|}{ Prob. } \\
\hline $\mathrm{C}$ & $?$ & 0.1321 & 0.7387 & 0.1744 & 0.8366 & \\
\hline IFRS & - & -0.4208 & 0.2020 & -4.2331 & 0.0161 & $* *$ \\
\hline SPEC & - & -0.2815 & 0.5678 & -1.0061 & 0.2999 & \\
\hline IFRS*SPEC & - & -0.0828 & 0.1626 & -1.0000 & 0.2971 & \\
\hline SIZE & $+/-$ & 0.1450 & 0.0255 & 5.7608 & 0.0000 & $* * *$ \\
\hline LEV & $+/-$ & -0.2916 & 0.0862 & -3.3587 & 0.0009 & $* * *$ \\
\hline $\mathrm{OCF}$ & $+/-$ & 1.3757 & 0.4571 & 3.0238 & 0.0020 & $* * *$ \\
\hline GROW & $+/-$ & -0.1078 & 0.0466 & -2.2610 & 0.0216 & $* *$ \\
\hline LOSS & $+/-$ & -0.8011 & 0.1185 & -6.7875 & 0.0000 & $* * *$ \\
\hline MCAP & $+/-$ & 0.2505 & 0.1346 & 1.8896 & 0.0548 & $*$ \\
\hline C_IND & $+/-$ & 0.2374 & 0.1469 & 1.6414 & 0.0906 & $*$ \\
\hline C_MAL & $+/-$ & 0.1885 & 0.1393 & 1.2891 & 0.1800 & \\
\hline C_SIN & $+/-$ & -0.0308 & 0.1847 & -0.1723 & 0.8403 & \\
\hline C_THA & $+/-$ & 0.4846 & 0.0771 & 6.2714 & 0.0000 & $* * *$ \\
\hline C_VIE & $+/-$ & 0.3329 & 0.1016 & 3.2513 & 0.0013 & $* * *$ \\
\hline $\mathrm{N}$ & & & & 398 & & \\
\hline R-squared & & & & 0.5279 & & \\
\hline Adjusted R-squared & & & & 0.5005 & & \\
\hline Prob(F-statistic) & & & & 0.0000 & & \\
\hline \multicolumn{7}{|c|}{$\begin{array}{l}\text { Table Description: } \\
* * * \text { Significant at level } 1 \% \text {; ** Significant at the } 5 \% \text { level; * Significant at level } 10 \% \\
\text { The dependent variable in this model is ADAC. The independent variables in this model are: (i) IFRS: Index of IFRS } \\
\text { convergence degree in a country; (ii) SPEC: Dummy auditor variable, value } 1 \text { for companies audited by auditor with } \\
\text { industry specialization, and value } 0 \text { for other; (iii) SIZE: Natural logarithm of the total assets of the company; (iv) LEV: } \\
\text { Natural logarithm of total debt / total assets; (v) OCF: Natural logarithm of cash flows from operating activities / total } \\
\text { assets; (vi) GROW: Natural logarithm of market value / book value; (vii) LOSS: Dummy variable, } 1 \text { for negative net } \\
\text { profit and } 0 \text { for vice versa; (viii) MCAP: Country Market Capitalization / GDP; (ix) CRTY Dummy variables, } 1 \text { for the } \\
\text { country concerned and } 0 \text { for other, the Philippines as country of reference. }\end{array}$} \\
\hline
\end{tabular}

In the t test analysis per variable, the IFRS variable (Degrees of IFRS Convergence) has a significant effect on the earnings quality described by the discretionary accruals with the direction of the negative relationship. These results are in line with the results of the previous model. The SPEC (Specialization Auditor) variable has no significant effect on the quality of earnings described by the discretionary accruals value despite having negative relationship direction. That is, there does not seem to be a link between auditor specialization and earnings quality. This is contrary to the conclusions drawn by Gerayli et al. (2011). Nevertheless, the results are similar to the results obtained by the previous model which draw the conclusion that in general audit quality control (in this case indicated by auditor specialization) has no effect on earnings management.

The IFRS * SPEC interaction variable in this model does not show a significant effect, and does not affect the significance of other independent variables as well. Thus, it appears that there is no moderating influence on this model. Thus, it can be concluded that hypothesis $3 \mathrm{~b}$ which states the level of IFRS convergence to local 
ENTREPRENEURSHIP AND SUSTAINABILITY ISSUES

ISSN 2345-0282 (online) http://jssidoi.org/jesi/ 2019 Volume 7 Number 1 (September) http://doi.org/10.9770/jesi.2019.7.1(9)

accounting standards will reinforce the positive influence of the auditor industry's specialization on the quality of earnings is not accepted.

\subsection{Additional Test}

From the descriptive statistics that have been obtained, there appears to be a considerable difference between the countries sampled. Singapore, for example, which is the country with the highest GDP per capita among sample countries, has a per capita GDP of more than 50,000 USD by 2015, almost 25 times the GDP per capita in Vietnam, which is around 2,000 USD. Due to such a large difference, in addition regression is made for all four models and excluding data from Singapore. Thus, the remaining 348 sample data from five countries other than Singapore (Table 6).

Table 6. Regression Result Excluding Observation from Singapore

\begin{tabular}{|c|c|c|c|c|c|c|c|c|c|c|c|c|c|}
\hline \multirow{3}{*}{\begin{tabular}{|c|}
$\begin{array}{c}\text { Variabel } \\
\text { Independen }\end{array}$ \\
IFRS \\
\end{tabular}} & \multirow{3}{*}{\begin{tabular}{|c|}
$\begin{array}{c}\text { Ekspektasi } \\
\text { Tanda }\end{array}$ \\
- \\
\end{tabular}} & \multicolumn{3}{|c|}{ Model 1a } & \multicolumn{3}{|c|}{ Model 1b } & \multicolumn{3}{|c|}{ Model 2a } & \multicolumn{3}{|c|}{ Model 2b } \\
\hline & & \multirow{2}{*}{$\begin{array}{l}\text { Coef } \\
-0.2162\end{array}$} & \multicolumn{2}{|c|}{ Prob. } & \multirow{2}{*}{\begin{tabular}{|l|} 
Coef \\
-0.2122
\end{tabular}} & \multicolumn{2}{|c|}{ Prob. } & \multirow{2}{*}{\begin{tabular}{l|} 
Coef \\
-0.1543 \\
\end{tabular}} & \multicolumn{2}{|c|}{ Prob. } & \multirow{2}{*}{\begin{tabular}{l|} 
Coef \\
-0.2056 \\
\end{tabular}} & \multicolumn{2}{|c|}{ Prob. } \\
\hline & & & 0.0019 & $* *$ & & 0.0027 & $* *$ & & 0.1068 & & & 0.0566 & * \\
\hline $\mathrm{BIG}$ & - & -0.1748 & 0.0001 & $* * *$ & & & & 0.0879 & 0.7486 & & & & \\
\hline SPEC & - & & & & -0.0604 & 0.1871 & & & & & -0.0209 & 0.9380 & \\
\hline IFRSBIG & - & & & & & & & -0.0797 & 0.3228 & & -0.0126 & 0.8799 & \\
\hline IFRSSPEC & - & & & & & & & & & & & & \\
\hline $\mathrm{C}$ & Tidak ada & 0.0660 & 0.8303 & & 0.2430 & 0.4877 & & 0.1016 & 0.1825 & & 0.2164 & 0.5802 & \\
\hline \multicolumn{14}{|l|}{\begin{tabular}{|l|} 
Variabel Kontrol \\
\end{tabular}} \\
\hline SIZE & $+/-$ & 0.1629 & 0.0000 & $* * *$ & 0.1533 & 0.0000 & $* * *$ & 0.1640 & 0.0000 & $* * *$ & 0.1535 & 0.0000 & $* * *$ \\
\hline $\mathrm{LEV}$ & $+/-$ & -0.2436 & 0.0000 & $* * *$ & -0.2385 & 0.0000 & $* * *$ & -0.2435 & 0.0000 & $* * *$ & -0.2370 & 0.0000 & $* * *$ \\
\hline OCF & $+/-$ & 1.6900 & 0.0000 & $* * *$ & 1.6256 & 0.0000 & $* * *$ & 1.6714 & 0.0000 & $* * *$ & 1.5590 & 0.0000 & $* * *$ \\
\hline GROW & $+/-$ & -0.1495 & 0.0000 & $* * *$ & -0.1458 & 0.0000 & $* * *$ & -0.1482 & 0.0000 & $* * *$ & -0.1445 & 0.0000 & $* * *$ \\
\hline LOSS & $+/-$ & -0.9035 & 0.0000 & $* * *$ & -0.8987 & 0.0000 & $* * *$ & -0.8967 & 0.0000 & $* * *$ & -0.9028 & 0.0000 & $* * *$ \\
\hline MCAP & $+/-$ & 0.1400 & 0.0524 & $*$ & 0.1219 & 0.0872 & $*$ & 0.1237 & 0.0825 & $*$ & 0.1237 & 0.0893 & $*$ \\
\hline \multicolumn{2}{|c|}{$\mathrm{N}$} & 350.0000 & & & 350.0000 & & & 350.0000 & & & 350.0000 & & \\
\hline \multicolumn{2}{|c|}{ R-squared } & 0.5512 & & & 0.5241 & & & 0.5561 & & & 0.5168 & & \\
\hline \multicolumn{2}{|c|}{ Adjusted R-squared } & 0.5341 & & & 0.5099 & & & 0.5349 & & & 0.5194 & & \\
\hline \multicolumn{2}{|c|}{ F-statistic } & 40.8088 & & & 39.3264 & & & 37.3993 & & & 34.8622 & & \\
\hline \multicolumn{2}{|c|}{ Prob(F-statistic) } & 0.0000 & & & 0.0000 & & & 0.0000 & & & 0.0000 & & \\
\hline
\end{tabular}

From the regression results shown in Table 9, it appears that in general the regression results obtained are similar to the regression results with the Singapore state included. The same relative value of significance is obtained in models $1 \mathrm{~b}, 2 \mathrm{a}$ and $2 \mathrm{~b}$ either by including country data of Singapore or not. As for model 1a, in the regression without entering Singapore data, the BIG variable value showing the dimension as the quality dimension of the auditor is significantly negative to the discretionary accruals, which means supporting the hypothesis $2 \mathrm{a}$ that the firm's earnings quality audited by the auditor of Big-4 auditors is higher than the quality the company's earnings audited by auditors of non Big-4 audit firms. When Singapore is included, this variable becomes insignificant because $91 \%$ or almost all public companies in Singapore are audited by Big-4 auditors, the highest among other countries. 


\section{ENTREPRENEURSHIP AND SUSTAINABILITY ISSUES}

ISSN 2345-0282 (online) http://jssidoi.org/jesi/ 2019 Volume 7 Number 1 (September) http://doi.org/10.9770/jesi.2019.7.1(9)

\section{Conclusions}

After analyzing the six sample countries, it can be concluded from this research that the higher the degree of IFRS convergence, the lower the likelihood of discretionary accruals, which means that the earnings quality will be better. These results are consistent with the research of Daske and Gunther (2006), Chiu et al., (2013), Dimitropoulos et al. (2013) and Ismail et al. (2013) that examines the effect of standards on the quality of financial statements with the result that in general the universal standard (IFRS) has a positive effect on the quality of financial statements.

The attributes associated with the quality of auditors, both the size and speciality of auditors have no significant effect on the quality of earnings described by the value of discretionary accruals. Meanwhile, the degree of IFRS Convergence does not indicate the effect of moderation on the relationship between audit quality as illustrated by size and auditor specialization with earnings quality. Thus, the degree of IFRS convergence has no role of moderation of IFRS convergence degree to the effect of audit quality with the earnings quality. This lack of significance is likely due to the fact that most sample companies have been audited by Big-4 auditors or audit firm with industry specialization.

Suggestions for further research are as follows: (i) added dimension of earnings quality dimension and updating of measurement method so that earnings quality measurement will be more accurate; (ii) The addition of auditor quality measurement so that auditor quality will be more accurately measured; (iii) The use of samples from different industries and regions with clear struc- tures, which may lead to differences that may occur between industries and regions; (iv) Research conducted within a period of several years, with the year through the crisis / recession, so it looks the difference in conditions between normal conditions with the conditions during the crisis.

\section{References}

Abbott, L.J., Parker, S. and Peters, G.F. 2004. Audit committee characteristics and restatements. Auditing: A Journal of Practice \& Theory, 23(1), pp.69-87. https://doi.org/10.2308/aud.2004.23.1.69

Adibah Wan Ismail, W., Anuar Kamarudin, K., van Zijl, T. and Dunstan, K. 2013. Earnings quality and the adoption of IFRS-based accounting standards: Evidence from an emerging market. Asian Review of Accounting, 21(1), pp.53-73. https://doi.org/10.1108/13217341311316940

Anggraeni, M.D., and Wardhani, R. 2017. The Effect of Leverage and IFRS Convergence on Earnings Management through Real Activities Manipulation in Asia. Asian Journal of Business and Accounting, 10(1), pp.87-125. Available at: <https://ajba.um.edu.my/article/view/3476>. Date accessed: 16 Apr 2019.

Ashbaugh H., and Pincus M. 2001. Domestic Accounting Standards, International Accounting Standards, and the Predictability of Earnings. Journal of Accounting Research, 39, pp. 417-434. https://doi.org/10.1111/1475-679X.00020

Balsam, Steven, Jagan Krishnan, and Joon S. Yang. 2003. Auditor Industry Specialization and Earnings Quality. AUDITING: A Journal of Practice \& Theory, September 2003, 22(2), pp. 71-97. https://doi.org/10.2308/aud.2003.22.2.71

Barth, M.E., Landsman, W.R. and Lang, M.H. 2008. International accounting standards and accounting quality. Journal of Accounting Research, 46(3), pp.467-498. https://doi.org/10.1111/j.1475-679X.2008.00287.x

Beatty, Anne, Chamberlain, Sandra and Magliolo, Joseph. 1996. An empirical analysis of the economic implications of fair value accounting for investment securities, Journal of Accounting and Economics, 22(1-3), pp. 43-77. https://doi.org/10.1016/S0165$\underline{4101(96) 00429-6}$

Chiu, T., Lee, E., Walker, M., \& Zeng, C. 2013. Does IFRS convergence affect financial reporting quality in China. ACCA research report, 131 . 


\section{ENTREPRENEURSHIP AND SUSTAINABILITY ISSUES}

ISSN 2345-0282 (online) http://jssidoi.org/jesi/ 2019 Volume 7 Number 1 (September) http://doi.org/10.9770/jesi.2019.7.1(9)

Cohen, D.A. 2003. Quality of financial reporting choice: Determinants and economic consequences. Working paper http://dx.doi.org/10.2139/ssrn.422581

Craswell, A.T., Francis, J.R. and Taylor, S.L. 1995. Auditor brand name reputations and industry specializations. Journal of Accounting and Economics, 20(3), pp.297-322. https://doi.org/10.1016/0165-4101(95)00403-3

Cuijpers, R., \& Buijink, W. 2005. Voluntary adoption of non-local GAAP in the European Union: A study of determinants and consequences. European Accounting Review, 14(3), pp. 487-524. https://doi.org/10.1080/0963818042000337132

Daske, Holger and Gebhardt, Günther. 2006. International financial reporting standards and experts' perceptions of disclosure quality, Abacus, 42(3-4), pp. 461-498. https://doi.org/10.1111/j.1467-6281.2006.00211.x

DeAngelo, L.E. 1981. Auditor size and audit quality. Journal of Accounting and Economics, 3(3), pp. 183-199. https://doi.org/10.1016/0165-4101(81)90002-1

Dechow, P.M., Sloan, R.G. and Sweeney, A.P. 1995. Detecting earnings management. Accounting Review, pp.193-225. http://www.jstor.org/stable/248303

Deloitte, 2016. IAS Plus. From http://www.iasplus.com/en/resources/ifrs-topics/use-of-ifrs. Date accessed: 16 Apr 2019.

Dichev, I., Graham, J., Harvey, C.R. and Rajgopal, S. 2016. The misrepresentation of earnings. Financial Analysts Journal, 72(1), pp.2235. https://doi.org/10.2469/faj.v72.n1.4

Dimitropoulos, P.E., Asteriou, D., Kousenidis, D. and Leventis, S. 2013. The impact of IFRS on accounting quality: Evidence from Greece. Advances in Accounting, 29(1), pp.108-123. https://doi.org/10.1016/j.adiac.2013.03.004

Dunn, K.A. and Mayhew, B.W. 2004. Audit firm industry specialization and client disclosure quality. Review of Accounting Studies, 9(1), pp.35-58. https://doi.org/10.1023

Enomoto, M., Kimura, F. and Yamaguchi, T. 2015. Accrual-based and real earnings management: An international comparison for investor protection. Journal of Contemporary Accounting \& Economics, 11(3), pp.183-198. https://doi.org/10.1016/j.jcae.2015.07.001

Gerayli, M.S., Yanesari, A.M. and Ma'atoofi, A.R. 2011. Impact of audit quality on earnings management: evidence from Iran. International Research Journal of Finance and Economics, 66(1), pp.77-84. Retrieved from gorganiau.ac.ir/my doc/gorgan/professor/m.maatoofi/IRJFE 66 07.pdf. Date accessed: 16 Apr 2019.

Halabi, H. and Yi, L. 2015. Mandatory IFRS adoption and earnings quality: The impact of country-specific factors. Dissertation of Faculty of Social Science Essex Business School. Retrieved from https://repository.hkbu.edu.hk/hkbu_staff_publication/4844. Date accessed: 16 Apr 2019.

Ismail, W., Anuar Kamarudin, K., Van Zijl, T., \& Dunstan, K. 2013. Earnings quality and the adoption of IFRS-based accounting standards. Asian Review of Accounting, 21(1), pp. 53-73. https://doi.org/10.1108/13217341311316940

Jensen, M.C. and Meckling, W.H. 1976. Theory of the firm: Managerial behavior, agency costs and ownership structure. Journal of Financial Economics, 3(4), pp. 305-360. https://doi.org/10.1016/0304-405X(76)90026-X

Karamanou, I. and Nishiotis, G.P. 2009. Disclosure and the Cost of Capital: Evidence form the Market's Reaction to Firm Voluntary Adoption of IAS. Journal of Business Finance \& Accounting, 36, pp. 793-821. https://doi.org/10.1111/j.1468-5957.2009.02154.x

Krishnan, G.V. 2003. Audit quality and the pricing of discretionary accruals. Auditing: A Journal of Practice \& Theory, 22(1), pp.109-126. https://doi.org/10.2308/aud.2003.22.1.109

Narkuniené, J., Ulbinaité, A. 2018. Comparative analysis of company performance evaluation methods. Entrepreneurship and Sustainability Issues, 6(1), pp. 125-138. http://doi.org/10.9770/jesi.2018.6.1(10)

Solikhah, B., Della Firmansyah, N. and Pirzada, K. 2017. Influence of effective BOC on choice of auditor, Pertanika Journal of Social Sciences \& Humanities 26 (S) Nov. Retrieved from http://www.pertanika.upm.edu.my/Pertanika\%20PAPERS/JSSH\%20Vol.\%2025\%20(S)\%20Nov.\%202017/22\%20JSSH(S)-0608-20176thProof.pdf. Date accessed: 16 Apr 2019. 


\section{ENTREPRENEURSHIP AND SUSTAINABILITY ISSUES}

ISSN 2345-0282 (online) http://jssidoi.org/jesi/ 2019 Volume 7 Number 1 (September) http://doi.org/10.9770/jesi.2019.7.1(9)

Pirzada, K. 2016. Providers and Users'perception of Voluntary Need of Human Resource Disclosure: A Content Analysis. Polish Journal of Management Studies, 14(2), pp. 232-242. Retrieved from https://ideas.repec.org/a/pcz/journl/v14y2016i1p232-242.html. Date accessed: 16 Apr 2019.

Reynolds, J. K., \& Francis, J. R. 2000. Does size matter? The influence of large clients on office-level auditor reporting decisions. Journal of Accounting and Economics, 30(3), pp. 375-400. https://doi.org/10.1016/S0165-4101(01)00010-6

Zemguliene, J., Valukonis, M. 2018. Structured literature review on business process performance analysis and evaluation, Entrepreneurship and Sustainability Issues, 6(1), pp. 226-252. http://doi.org/10.9770/jesi.2018.6.1(15)

Wardhani, R., Utama, S. and Rossieta, H. 2015. The effect of governance system and degree of convergence to IFRS on the quality of financial reporting: Evidence from Asia. Corporate Ownership and Control, 12(4), pp. 409-423. https://doi.org/10.22495/cocv12i4c3p8

Zahra NADHIR is a student from Faculty of Economic and Business Universitas Indonesia. This paper is written with her supervisor as her thesis.

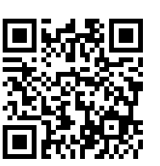

Ratna WARDHANI is Associate Professor at Faculty of Economic and Business Universitas Indonesia. She is a senior lecturer and also senior consultant. She has published several articles in national and international journals. Her research interest covers broad range of topics such as corporate governance, financial accounting, public sector, etc.

ORCID ID: https://orcid.org/0000-0002-7691-7443

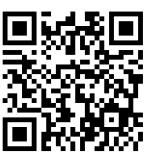

Copyright (C) 2019 by author(s) and VsI Entrepreneurship and Sustainability Center This work is licensed under the Creative Commons Attribution International License (CC BY). http://creativecommons.org/licenses/by/4.0/

CC) (i) Open Access 